\title{
Intestine-Specific Homeobox
}

National Cancer Institute

\section{Source}

National Cancer Institute. Intestine-Specific Homeobox. NCI Thesaurus. Code C116413.

Intestine-specific homeobox (245 aa, $\sim 27 \mathrm{kDa}$ ) is encoded by the human ISX gene. This protein is involved in intestine tissue-specific regulation of gene transcription. 